\title{
DOE REPORT
}

Because this DOE grant was abruptly terminated without warning, this group was not able to accomplish the insertion of the biosensor genes into the mouse lines. They have been able to generate some of the mouse lines but have not been able to complete the ones that would give them the model systems that would allow them to investigate metastasis real-time in living tumors at the cellular level. Nonetheless, until the loss of funding, they have made progress in applications of the equipment to biological problems involving RNA and protein movement in living cells.

Products delivered

Imaging of gene expression in living cells and tissues, Singer $\mathrm{RH}$, Lawrence DS, Ovryn B, Condeelis J, J Biomed Optics 10:0514061-0514069, 2005.

This paper describes the method for activating single genes within cells and tissues.

Single Cell Gene Expression Profiling: Multiplexed Expression Fluorescence in situ Hybridization (FISH): Application to the Analysis of Cultured Cells. Levsky JM, Braut SA, Singer RH, Cell Biology: A Laboratory Handbook Volume 4, eds Celis JE, et al, 121-130. Academic Press, 2005.

This paper describes the methodology for single cell expression profiling in tissues.

Spatial regulation of beta-actin translation by Src-dependent phosphorylation of ZBP1, Huttelmaier S, Zenklusen D, Lederer M, Dictenberg J, Lorenz M, Meng X, Bassell GJ, Condeelis J, Singer RH, Nature 438:512-515, 2005.

This paper describes the mechanism by which the translational repressor of actin mRNA ZBP1 can effect regulation of cell motility and metastasis.

Visualization of mRNA translation in living cells, Rodriguez AJ, Shenoy SM, Singer RH, Condeelis J, J Cell Biol 175:67-76, 2006.

This work describes a method to visualize mRNA translation in single cells. 
Imaging mRNA movement from transcription sites to translation sites, Rodriguez AJ, Condeelis J, Singer RH, Dictenberg JB, Semin Cell Dev Biol 18:202-208, 2007.

This review describes current technology for visualizing mRNA from birth to death.

In vivo dynamics of RNA polymerase II transcription, Darzacq $X$, Shav-Tal $Y$, de Turris V, Brody Y, Shenoy SM, Phair RD, Singer RH, Nat Struct Mol Biol 14:796806, 2007.

This paper describes methods for visualizing gene transcription in real time and provides a systems modeling approach to understanding polymerase dynamics. (See News \& Views 14:788)

Nuclear microenvironment in cancer diagnosis and treatment, Pezo RC, Singer $\mathrm{RH}, \mathrm{J}$ Cell Biochem in press (2007). directly.

This work describes the environmental factors acting on the genes

The spatial order of transcription in mammalian cells, Levsky JM, Shenoy SM, Chubb JR, Hall CB, Capodieci P, Singer RH, J Cell Biochem in press (2007).

This work describes how active genes are spatially distributed throughout the nucleus.

ZBP1 Enhances Cell Polarity and Reduces Metastasis, Lapidus K, Wyckoff J, Mouneimne G, Lorenz M, Soon L, Condeelis J and Singer RH, JCS in press (2007) metastasis.

This work describes the role of the RNA binding protein in cell polarity and New Notes:

They continue to productively use the equipment provided by the DOE and are grateful for the opportunity to have obtained the instrumentation. They are trying to obtain NIH funding to continue the project originally funded by the DOE. The high speed imaging system has resulted in several breakthroughs, for instance in revealing the details of transcription and allowing a quantitative 
modeling approach that characterizes RNA regulation at the single-molecule single-cell level. 